\title{
Sozialwissenschaftliche Forschungen
}

Herausgegeben von der

Sozialwissenschaftlichen Arbeitsgemeinschaft Abteilung III, Heft 2

\section{Der Soziallohn}

\section{und seine wirtschaftliche Bedeutung}

\author{
Von \\ Gerhard Braun
}

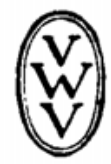

Berlin und Leipzig 1922

Vereinigung wissenschaftlicher Verleger

Walter de Gruyter \& Co.

vormals G. J. Göschen'sche Verlagshandlung - J. Guttentag, Verlags. buchhandlung - Georg Reimer Karl J. Trübner - Veit \& Comp 
